\title{
A renewable heat solution for water ingress in the Glasgow subway tunnel system
}

\author{
K. Ninikas ${ }^{1}$, N. Hytiris ${ }^{1}$, R. Emmanuel ${ }^{1}$, B. Aaen $^{1} \&$ S. McMillan ${ }^{2}$ \\ ${ }^{1}$ School of Engineering \& Built Environment, \\ Glasgow Caledonian University, Scotland, UK \\ ${ }^{2}$ Strathclyde Partnership for Transport, Scotland, UK
}

\begin{abstract}
With regards to renewable energy there is a need to take advantage of a wide variety of alternate energy sources to meet the Scottish Government's target of $100 \%$ of the nation's electricity requirements from renewable sources by 2020 (Scottish Government, 2011). One of these renewable sources could be the water of the old mine workings of Glasgow and any other sources available underground the region. In simple terms there is a potential to harvest heat energy from underground water by means of heat exchangers. In the same way, there is a potential for the wasted ingress water in the Glasgow subway system to be used for similar energy exploitation. In order to carry out the present research, the following tasks have been planned: measurements of temperature and flow of the water, identification of the water ingress locations inside the tunnels, quantification of the annual amount of water available, water sampling and analysis, selection of site for a pilot study. By using the latest energy efficient technologies available, the findings of this project are expected to lead us to the design of a cost-effective heat pump product for harnessing heat from the Glasgow subway tunnels.
\end{abstract}

Keywords: subsurface water, ground source heat pump, water flow, heat energy.

\section{Introduction}

Today in the UK only $2 \%$ of the energy produced comes from renewable sources. The UK government aims to increase this percentage to $15 \%$ by 2020 and to decarbonise the heat in buildings by 2050 . The Scottish government, according 
to the 2020 renewable route map for 2020 , targets $100 \%$ of the nation's electricity requirements to come from renewable sources.

Some of the renewable sources are biomass, wind, solar and tidal. One of these sources can be the geothermal potential and specifically, shallow geothermal energy, which is the scope of this project.

Research currently being carried out in Glasgow indicated that shallow mine workings are strongly capable in heat exploitation.

In the same way, in the subway railway system in Glasgow there is an abundance of ongoing water ingress. This water is currently being wasted by pumping into the local sewer system. There is a potential for it to be recycled in order to recover heat energy from it then for it to be used in residential areas located close to the subway system. Given the stable temperatures of this water, there is a possibility to take advantage of this relatively high temperature and use less energy to provide heating and hot water for commercial use.

The Glasgow subway forms a circle in the centre-west of the city. The entire passenger railway is underground, contained in twin tunnels, allowing clockwise circulation on the 'outer' circle and anticlockwise on the 'inner'. Fifteen stations are distributed along the route length of just over ten kilometers. The River Clyde dissects the circular route, with eight stations in the north and seven in the south, as shown in Figure 1.

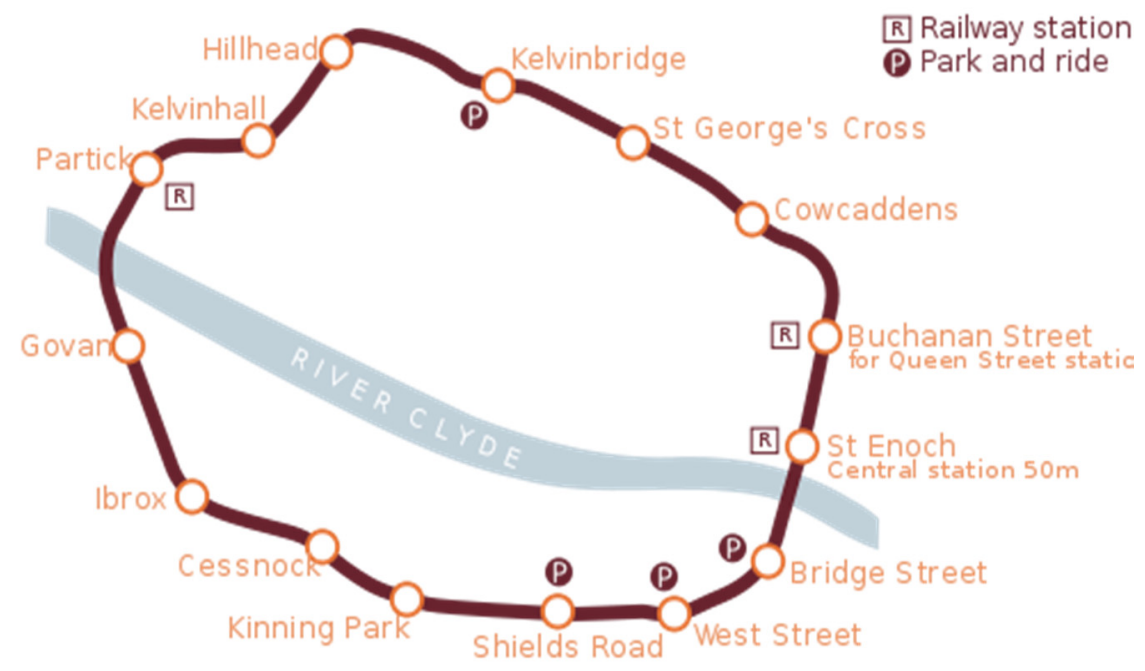

Figure 1: A typical Glasgow subway map.

The water ingress in the subway, instead of being discharged into the local sewer system, can be recycled to form a source of power generating heat for the subway itself with the possibility of providing commercial and space heating to premises on the surface. This will be achieved by means of a water source heat pump. 
Heat pumps have always been the key technology in the use of excess heat in lower temperatures. They use compression (the same principal as a refrigerator) to extract tepid low grade heat to produce heat for space and/or water heating in general. They can also be reversed to produce cooling. Heat pumps, as shown in Figure 2, are designed to move thermal energy to the opposite direction of spontaneous heat flow by absorbing heat from a cold space and releasing it into a warmer one. A heat pump uses some amount of external power to accomplish the work of transferring energy from the heat source to the destination (space heating/hot water).

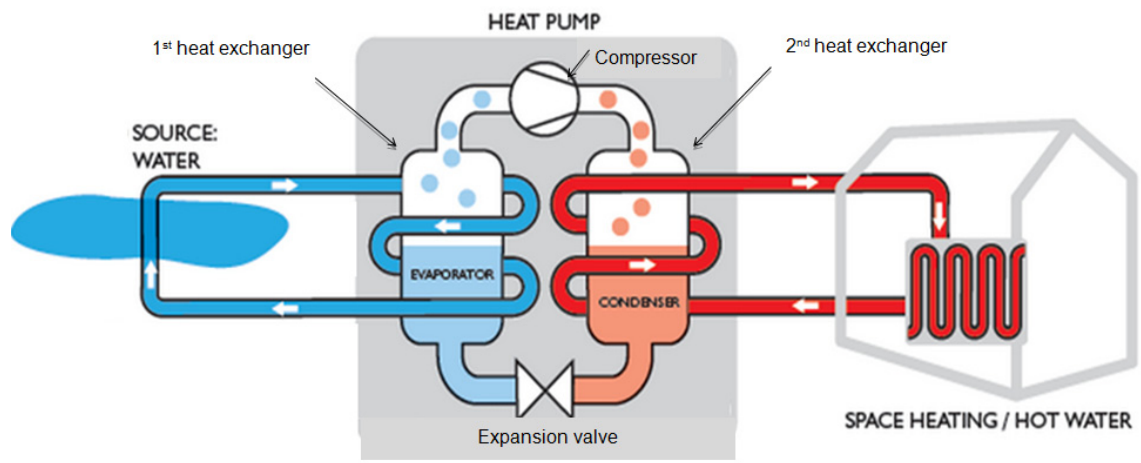

Figure 2: A typical diagram of a water source heat pump.

\section{Methodology}

\subsection{Methodology outline}

A series of measurements have been started since the $1^{\text {st }}$ of May 2014 and these consisted of the following: measurements of temperature and flow of the ingress water, consideration of geological and geotechnical parameters to identify sites suitable for heat pump locations. This procedure will continue until the end of this project (end of 2015) in order to calculate the seasonal variations of the water ingress. In addition to the above, water sampling has been carried out at all sumps (Figure 3) for the chemical analysis of the water regime.

Six water samples from six sumps were chosen to be analysed (Table 1). This was because these are the most potential heat pump installation points. This decision was based on the following: previous onsite surveys indicated the higher flow rate in these six sumps. Up to now, out of these six sumps we have water flux in only three of them. This is because summer months flow is in the lowest per annum level. We have noticed a flow of less than half a litre per second from May 2014 to August 2014 for the three out of the six sumps (sumps: 9, 11 and 16). We expect to have a higher water flux during this winter (2014-2015) and due to these measurements we will re-evaluate the new data in April 2015. 


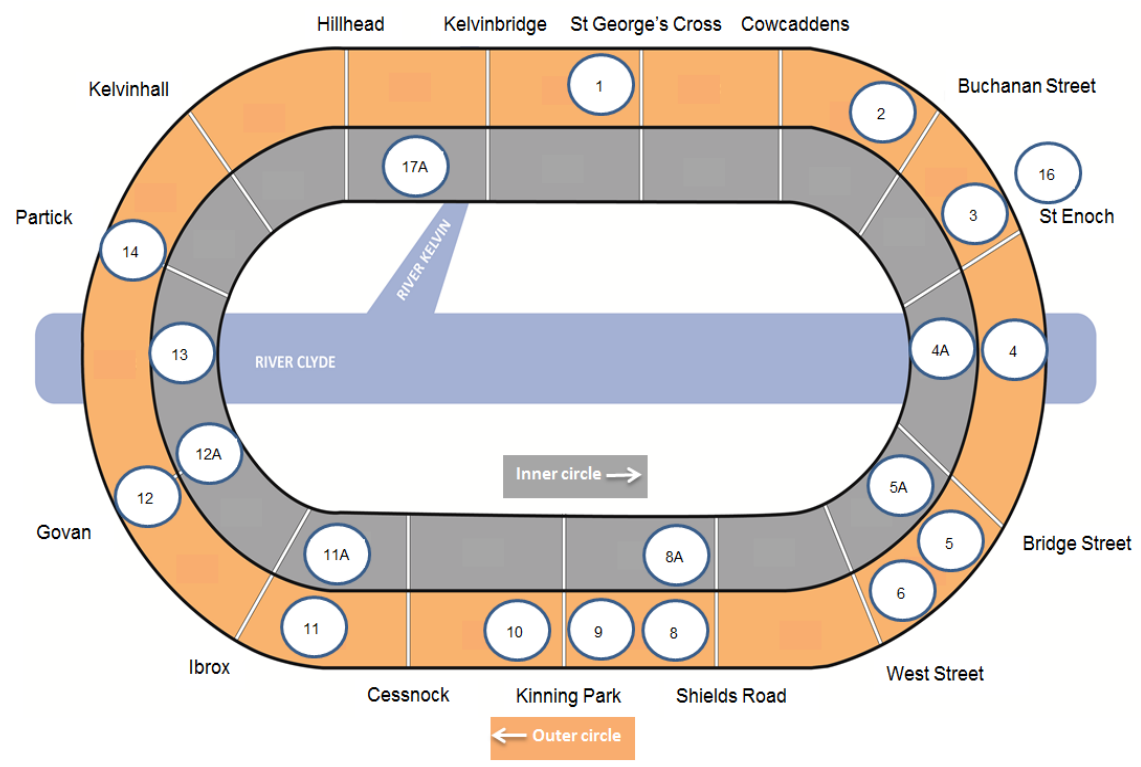

Figure 3: Sump locations in the subway.

Table 1: Water sample chemical analysis breakdown.

\begin{tabular}{|l|l|l|}
\hline \multicolumn{3}{|c|}{ Proposed analysis for water samples } \\
\hline $\mathrm{pH}$ & Magnesium & Lead \\
\hline Electrical conductivity & Sodium & Manganese \\
\hline Total dissolved solids & Potassium & Nickel \\
\hline Oxidation reduction potential & Cadmium & Zinc \\
\hline Total petroleum hydrocarbons & Chromium & Arsenic \\
\hline Sulphate & Copper & Antimony \\
\hline Calcium & Iron & Molybdenum \\
\hline
\end{tabular}

The following measurements shown in Table 2 have been performed using a portable water ultrameter (Figure 4) $(\mathrm{pH}$, electrical conductivity, total dissolved solids and oxidation reduction potential).

By measuring $\mathrm{pH}$ we determine the acidity of the water. Electrical conductivity is the measure of a material's ability to accommodate the transport of an electric charge. Total dissolved solids (TDS) are the total amount of mobile charged ions, including minerals, salts or metals dissolved in a given volume of water. 
Table 2: Chemical analysis results from the portable water ultrameter.

\begin{tabular}{|c|c|c|c|c|c|c|c|c|}
\hline & Abr. & Units & \multicolumn{5}{|c|}{ Analysis results - sample names (see figure 3) } \\
\hline $\begin{array}{c}\text { Analysis } \\
\text { for: }\end{array}$ & & $\mathbf{1 7 A}$ & $\mathbf{1}$ & $\mathbf{2}$ & $\mathbf{1 6}$ & $\mathbf{9}$ & $\mathbf{1 1}$ \\
\hline $\begin{array}{c}\text { Acidity or } \\
\text { alcalinity }\end{array}$ & $\mathrm{pH}$ & 6.8 & 6.7 & 6.5 & 7.0 & 6.2 & 8.1 \\
\hline $\begin{array}{c}\text { Electrical } \\
\text { conductivity }\end{array}$ & & $\mu \mathrm{S} / \mathrm{cm}$ & 662 & 446 & 770 & 647 & 579 & 574 \\
\hline $\begin{array}{c}\text { Total } \\
\text { Dissolved } \\
\text { Solids }\end{array}$ & $\mathrm{TDS}$ & $\mathrm{ppm}$ & 459 & 81 & 498 & 448 & 413 & 399 \\
\hline $\begin{array}{c}\text { Oxidation } \\
\text { Reduction } \\
\text { Potential }\end{array}$ & ORP & $\mathrm{mV}$ & 122 & 185 & 25 & 231 & 252 & 234 \\
\hline
\end{tabular}

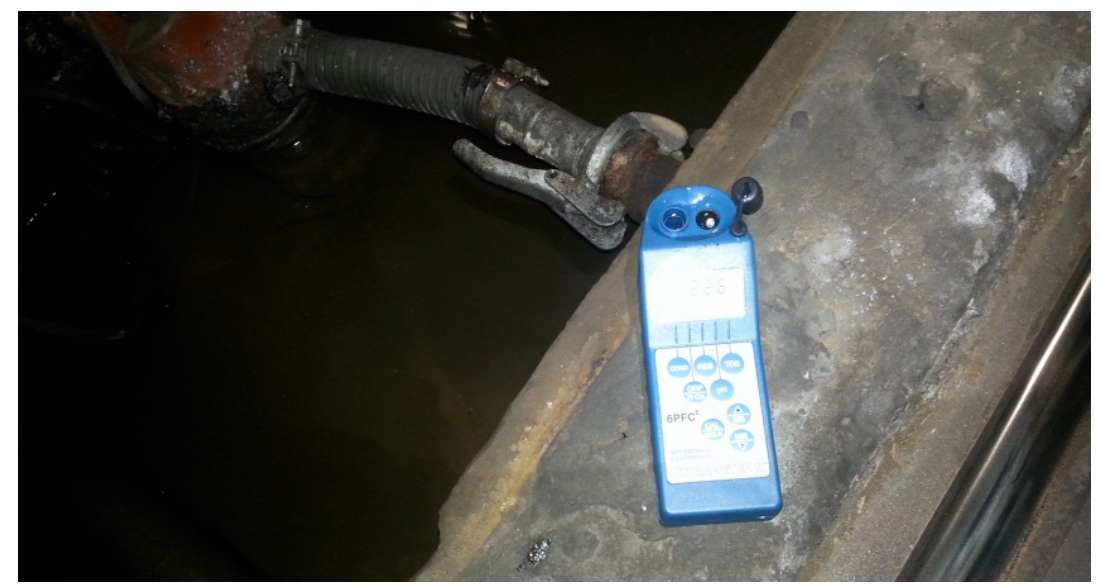

Figure 4: Portable water ultrameter.

The measurement results shown in Table 3 have been issued from an accredited laboratory in Glasgow.

The highlighted cells indicate values above the thresholds. The light green coloured cells indicate values slightly above the thresholds for drinking water. The light red coloured cells indicate values at least five times higher above the thresholds for drinking water.

The water from sumps 1 and 17A have no signs of pollutants. The water from sump 2 has a high level of iron and manganese compared with the drinking water thresholds (Table 4). 
Table 3: Chemical analysis results from the laboratory.

\begin{tabular}{|c|c|c|c|c|c|c|c|c|}
\hline \multirow[b]{2}{*}{ Analysis for: } & \multirow[t]{2}{*}{ Abr. } & \multirow[t]{2}{*}{ Units } & \multicolumn{6}{|c|}{ Analysis results - sample names (see figure 3) } \\
\hline & & & 17A & 1 & 2 & 16 & 9 & 11 \\
\hline $\begin{array}{c}\text { Total } \\
\text { Petroleum } \\
\text { Hydrocarbons }\end{array}$ & TPH & $\mathrm{mg} / \mathrm{l}$ & $<0.01$ & $<0.01$ & $<0.01$ & - & - & - \\
\hline Sulphate & $\mathrm{SO} 4$ & $\mathrm{mg} / \mathrm{l}$ & 80 & 116 & 167 & 251 & 187 & 107 \\
\hline Calcium & $\mathrm{Ca}$ & $\mathrm{mg} / \mathrm{l}$ & 86.8 & 111 & 139 & 116 & 192 & 138 \\
\hline Magnesium & $\mathrm{Mg}$ & $\mathrm{mg} / \mathrm{l}$ & 22.3 & 33.7 & 38.5 & 33.3 & 32.6 & 18.7 \\
\hline Sodium & $\mathrm{Na}$ & $\mathrm{mg} / \mathrm{l}$ & 33.1 & 68.2 & 108 & 78.8 & 222 & 53 \\
\hline Potassium & $\mathrm{K}$ & $\mathrm{mg} / \mathrm{l}$ & 8.2 & 10.0 & 15.3 & 16.7 & 12.6 & 15.2 \\
\hline Cadmium & $\mathrm{Cd}$ & $\mathrm{mg} / \mathrm{l}$ & $<0.0002$ & $<0.0002$ & $<0.0002$ & $<0.0002$ & $<0.0002$ & 0.0008 \\
\hline Chromium & $\mathrm{Cr}$ & $\mathrm{mg} / \mathrm{l}$ & 0.001 & 0.001 & 0.003 & 0.007 & $<0.001$ & 0.041 \\
\hline Copper & $\mathrm{Cu}$ & $\mathrm{mg} / \mathrm{l}$ & 0.003 & $<0.001$ & 0.013 & 0.027 & 0.002 & 0.446 \\
\hline Iron & $\mathrm{Fe}$ & $\mathrm{mg} / \mathrm{l}$ & 1.21 & 0.042 & 21.4 & 7.26 & 1.84 & 56.2 \\
\hline Lead & $\mathrm{Pb}$ & $\mathrm{mg} / \mathrm{l}$ & 0.0005 & $<0.0005$ & 0.0032 & 0.0148 & $<0.0005$ & 0.188 \\
\hline Manganese & $\mathrm{Mn}$ & $\mathrm{mg} / \mathrm{l}$ & 0.094 & 0.004 & 0.674 & 0.098 & 0.184 & 5.74 \\
\hline Nickel & $\mathrm{Ni}$ & $\mathrm{mg} / \mathrm{l}$ & 0.0013 & 0.0026 & 0.1006 & 0.0069 & 0.0024 & 0.0457 \\
\hline Zinc & $\mathrm{Zn}$ & $\mathrm{mg} / \mathrm{l}$ & $<0.01$ & $<0.01$ & 0.2 & 0.08 & $<0.01$ & 2.21 \\
\hline Arsenic & As & $\mu \mathrm{g} / \mathrm{l}$ & 0.5 & 0.4 & 70.5 & 2.2 & 0.9 & 7.7 \\
\hline Antimony & $\mathrm{Sb}$ & $\mu \mathrm{g} / 1$ & 1.2 & 2.2 & 2.2 & 2.5 & 2.1 & 3.3 \\
\hline Molybdenum & Mo & $\mu \mathrm{g} / 1$ & 0.5 & 0.7 & 0.2 & 13.9 & 4.0 & 16.5 \\
\hline
\end{tabular}


Table 4: Water thresholds.

\begin{tabular}{|c|c|c|c|c|c|c|}
\hline & Symbol & Units & \multicolumn{4}{|c|}{ Thresholds } \\
\hline Acidity or alcalinity & & $\mathrm{pH}$ & & & & \\
\hline Electrical conductivity & & $\mu \mathrm{S} / \mathrm{cm}$ & & & & \\
\hline Total Dissolved Solids & TDS & ppm & 500 & ppm & & \\
\hline $\begin{array}{l}\text { Oxidation Reduction } \\
\text { Potential }\end{array}$ & OPR & $\mathrm{mV}$ & & & & \\
\hline $\begin{array}{l}\text { Total Petroleum } \\
\text { Hydrocarbons }\end{array}$ & $\mathrm{TPH}$ & $\mathrm{mg} / \mathrm{l}$ & & & & \\
\hline Sulphate** & SO4 & $\mathrm{mg} / \mathrm{l}$ & 250000 & $\mu \mathrm{g} / 1$ & 250 & $\mathrm{mg} / \mathrm{l}$ \\
\hline Calcium** & $\mathrm{Ca}$ & $\mathrm{mg} / 1$ & & & & \\
\hline Magnesium ** & $\mathrm{Mg}$ & $\mathrm{mg} / \mathrm{l}$ & & & & \\
\hline Sodium* & $\mathrm{Na}$ & $\mathrm{mg} / 1$ & 200000 & $\mu \mathrm{g} / 1$ & 200 & $\mathrm{mg} / \mathrm{l}$ \\
\hline Potassium** & $\mathrm{K}$ & $\mathrm{mg} / \mathrm{l}$ & 82000 & $\mu \mathrm{g} / 1$ & 82 & $\mathrm{mg} / \mathrm{l}$ \\
\hline Cadmium* & $\mathrm{Cd}$ & $\mathrm{mg} / 1$ & 5 & $\mu \mathrm{g} / 1$ & 0.005 & $\mathrm{mg} / \mathrm{l}$ \\
\hline Chromium* & $\mathrm{Cr}$ & $\mathrm{mg} / \mathrm{l}$ & 50 & $\mu \mathrm{g} / 1$ & 0.05 & $\mathrm{mg} / \mathrm{l}$ \\
\hline Copper* & $\mathrm{Cu}$ & $\mathrm{mg} / \mathrm{l}$ & 2000 & $\mu \mathrm{g} / 1$ & 2 & $\mathrm{mg} / \mathrm{l}$ \\
\hline Iron $* * *$ & $\mathrm{Fe}$ & $\mathrm{mg} / 1$ & 1000 & $\mu \mathrm{g} / 1$ & 1 & $\mathrm{mg} / \mathrm{l}$ \\
\hline Lead* & $\mathrm{Pb}$ & $\mathrm{mg} / \mathrm{l}$ & 10 & $\mu \mathrm{g} / 1$ & 0.01 & $\mathrm{mg} / \mathrm{l}$ \\
\hline Manganese* & $\mathrm{Mn}$ & $\mathrm{mg} / \mathrm{l}$ & 50 & $\mu \mathrm{g} / 1$ & 0.05 & $\mathrm{mg} / 1$ \\
\hline Nickel* & $\mathrm{Ni}$ & $\mathrm{mg} / \mathrm{l}$ & 20 & $\mu \mathrm{g} / 1$ & 0.02 & $\mathrm{mg} / \mathrm{l}$ \\
\hline Zinc* & $\mathrm{Zn}$ & $\mathrm{mg} / 1$ & 5000 & $\mu \mathrm{g} / 1$ & 5 & $\mathrm{mg} / \mathrm{l}$ \\
\hline Arsenic*** & As & $\mu \mathrm{g} / 1$ & 50 & $\mu \mathrm{g} / 1$ & 0.05 & $\mathrm{mg} / \mathrm{l}$ \\
\hline Antimony* & $\mathrm{Sb}$ & $\mu \mathrm{g} / 1$ & 5 & $\mu \mathrm{g} / 1$ & 0.005 & $\mathrm{mg} / \mathrm{l}$ \\
\hline Molybdenum ** & Mo & $\mu \mathrm{g} / 1$ & 70 & $\mu \mathrm{g} / 1$ & 0.007 & $\mathrm{mg} / 1$ \\
\hline
\end{tabular}

$1 \mu \mathrm{g}$ (microgram) equals to one thousandth (1/1000) of $1 \mathrm{mg}$ (milligram).

* The threshold values are the drinking water limits from the Scottish Drinking Water Regulations. ** Sulphate, Calcium, Magnesium, Potassium, Molybdenum are not mentioned in the Scottish Drinking Water Regulations. Thresholds by the World Health Organization (WHO). *** Thresholds for river-basin water.

Where the table cells are empty there are no thresholds mentioned from the Scottish Environmental Protection Agency (SEPA). 


\subsection{Water flow measurement}

A digital ultrasonic flow meter with remote transducers (Figure 5 and 6) which provides precision water flow measurements has been purchased and used. This instrument provides us with accurate values of the water flux. Before each measurement we input the following necessary data to calibrate it: liquid that runs into the pipe, diameter of the pipe, material of the pipe: uPVC: (unplasticized polyvinyl chloride. A rigid, chemically resistant form of PVC used for pipework). The accuracy of this flow meter depends on the aforementioned parameters and reaches $99 \%$.

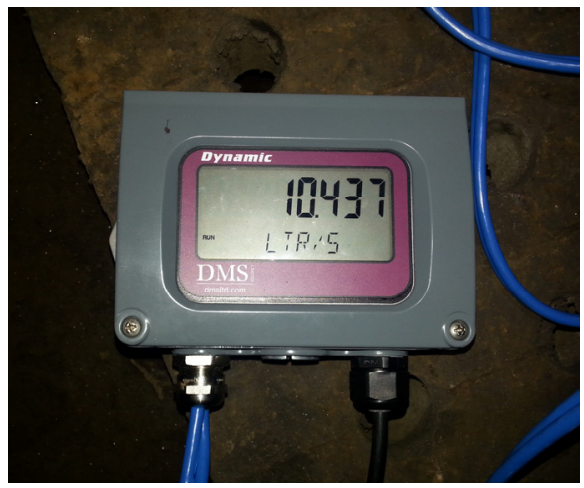

Figure 5: Ultrasonic flow meter.

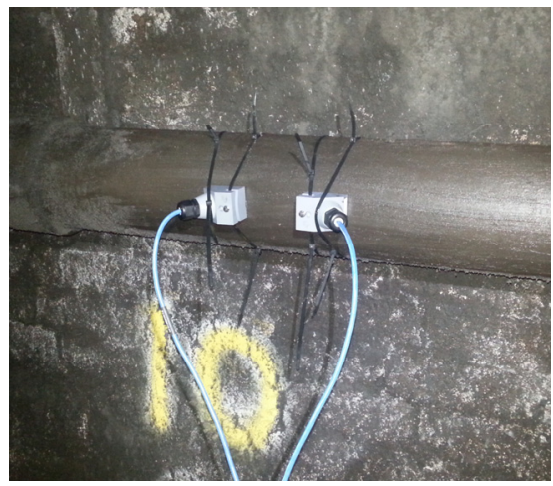

Figure 6: The remote transducers.

\subsection{3 Water temperature measurement}

Water temperature has been measured inside each sump. A digital probe thermometer (thermocouple) (Figures 7 and 8) has been used to record the temperature every $10 \mathrm{sec}$. The thermometer was kept in place for 2 minutes (as a minimum) so the minimum 12 temperature measurements were received from each measuring point. Atmospheric data has also been compiled in order to monitor if the changes in the weather, i.e. atmospheric temperature, pressure and rainfall, have any effect on the subsurface tunnel water. This was done by using the University's meteorological station. The average temperature and rainfall for each day of the site visits was captured and also public information from the Met Office website (http://www.metoffice.gov.uk) was accessed for atmospheric pressure and humidity data.

\section{Results of this work}

It seems that the quality of the water will not affect the selection of a heat pump. Even though some values (from the chemical analysis results) are higher than the 


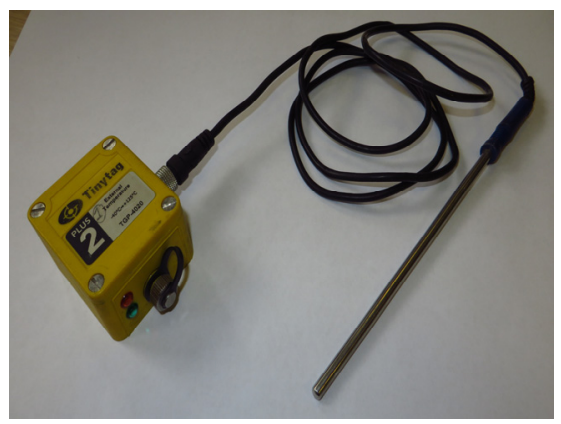

Figure 7: Digital thermometer.

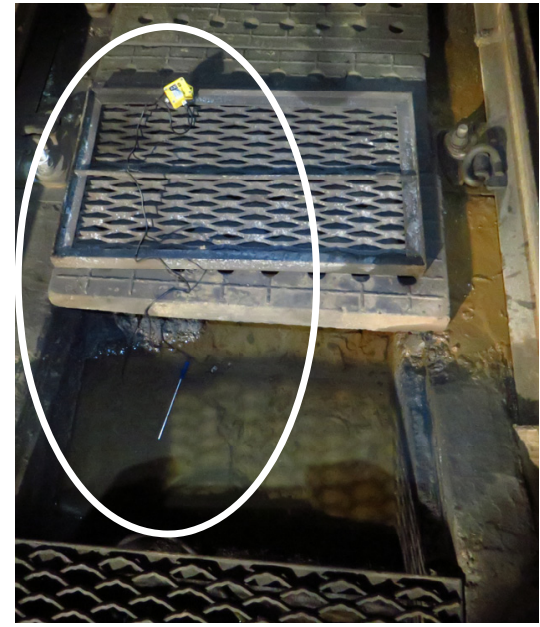

Figure 8: Digital thermometer inside the sump.

thresholds, this poses no threat for the use of this water through a heat pump. This is because the thresholds are for drinking water and the water that is above these thresholds is not going to be used directly for the heating circuit. As shown in Figure 2, the water that circulates in the first heat exchanger is a closed circuit and there is no possibility for it to be mixed with the water that circulates in the second heat exchanger. In the first heat exchanger we have the ground water and in the second heat exchanger we have the water that circulates inside the radiators, or inside the underfloor heating circuit.

We must bear in mind that only five months have elapsed since the beginning of this project. Only four sets of measurements have been achieved so far. These only indicate the water ingress during the summer period of 2014 in Glasgow.

In order to have a solid picture of the water regime (flow and temperature), another seven sets of measurements from September 2014 to March 2015 are expected. This data will lead us to the following steps which are: the research of the suitability of a heat pump product for harnessing heat from the subway tunnels, the preparation of a zoning map, a site selection for a pilot study, the design of the pilot study, the installation of a heat pump and finally the documentation and plan for further roll out of heat pumps through the subway system.

There is no direct relationship between water ingress and rainfall during summer months. Scotland, being in the Gulf Stream region, very often has no rainfall increases in the winter compared to the summer. During summer we have saturation in the ground so it is very common to see more subsurface water in the summer compared with the spring. There is no logical pattern in the flow rate in Tables 5, 6, and 7. The flux, although it varies in every sump, has a standard rate. During these first four months small fluxuations have been noticed on average ranges from $3.60 \mathrm{l} / \mathrm{s}$ to $12.10 \mathrm{l} / \mathrm{s}$. 
Factors that interfere with the water flux are the soil permeability, the tunnel lining, the geographical location of the sumps to nearby rivers and the weather.

Table 5: $\quad$ Results for sump 1.

\begin{tabular}{|l|c|c|c|c|}
\cline { 2 - 5 } \multicolumn{1}{c|}{} & \multicolumn{4}{c|}{2014} \\
\hline Sump 1 & May & Jun & Jul & Aug \\
\hline Mean tunnel water temperature $\left({ }^{\circ} \mathbf{C}\right)$ & 14.17 & 13.45 & 14.95 & 16.03 \\
\hline Flow rate (l/s) & 6.70 & 6.30 & 5.30 & 3.90 \\
\hline
\end{tabular}

Table 6: $\quad$ Results for sump 2.

\begin{tabular}{|l|c|c|c|c|}
\cline { 2 - 5 } \multicolumn{1}{c|}{} & \multicolumn{4}{c|}{2014} \\
\hline Sump 2 & May & Jun & Jul & Aug \\
\hline Mean tunnel water temperature $\left({ }^{\circ} \mathbf{C}\right)$ & 14.22 & 15.28 & 13.47 & 15.76 \\
\hline Flow rate (l/s) & 6.40 & 6.80 & 4.90 & 3.60 \\
\hline
\end{tabular}

Table 7: $\quad$ Results for sump 17A.

\begin{tabular}{|l|c|c|c|c|}
\cline { 2 - 5 } \multicolumn{1}{c|}{ Sump 17A } & \multicolumn{3}{c|}{2014} \\
\hline Mean tunnel water temperature $\left({ }^{\circ} \mathbf{C}\right)$ & 12.60 & 13.11 & 13.60 & 13.75 \\
\hline Mean flow rate (1/s) & 11.50 & 12.10 & 12.10 & 10.70 \\
\hline
\end{tabular}

\section{Conclusions}

- The renewable sources of energy may be dearer than conventional ones but they are playing a huge role in terms of carbon reductions.

- The use of the subsurface water in Glasgow is felt to be an excellent idea.

- The energy output (performance ratio) of a heat pump can be up to four times the energy input.

- The measurements results indicate that the maximum flow appears to be in sumps 1, 2 and 17A. 
- Due to the forthcoming measurement during autumn 2014 and winter 2014-2015 we expect to have more data available and a higher water flow in more than three sumps.

- The low operating costs of a heat pump, compared with conventional methods of heating, together with the sufficient flux of water in some sumps, are some promising factors for the exploitation of the waste water in the subway tunnels.

- The quality of the water poses no threat to the heat pump during its function.

- The waste water that is going to be used will have no interference with the water that will be used through a radiator for heating or through a buffer tank for domestic hot water.

\section{References}

[1] Banks, D. An Introduction to Thermogeology, 2007.

[2] The Scottish Government, 2020 Routemap for Renewable Energy in Scotland. http://www.scotland.gov.uk/Resource/0044/00441628.pdf

[3] The Scottish Government, Threshold values for groundwater. http://www.scotland.gov.uk/Publications/2010/01/06141049/7

[4] Scottish Environment Protection Agency http://www.sepa.org.uk/water/water_regulation.aspx

[5] World Health Organization. Chloride in drinking water. http://www.who.int/water_sanitation_health/dwq/chloride.pdf

[6] World Health Organization. Sulfade in drinking water. http://www.who.int/water_sanitation_health/dwq/chemicals/sulfate.pdf

[7] World Health Organization. Protecting Groundwater for Health. http://www.who.int/water_sanitation_health/publications/PGWsection1.pdf

[8] "River Basin Specific Pollutants" Water Framework Directive implementation in England and Wales: new and updated standards to protect the water environment. Page 20.

[9] https:/www.gov.uk/government/uploads/system/uploads/attachment_data/ file/307788/river-basin-planning-standards.pdf

[10] Total Dissolved Solids. http://www.tdsmeter.com/

[11] DMS flow meter. http://www.dmsltd.com/Water_Meters/DMS_Dynamic Large_Pipe_Non-Invasive_Flow_Meter

[12] Water ultrameter. http://www.myronl.com/products/ultrameter_II.htm 